Bangladesh J. Bot. 37(2): 127-131, 2008 (December)

\title{
EFFECTS OF DEFICIT IRRIGATION ON SOME YIELD CHARACTERISTICS OF SWEET CORN
}

\author{
Abdullah OKtem \\ Department of Field Crops, Faculty of Agriculture, Harran University, \\ 63200, Sanliurfa-Turkey \\ E-mail: aoktem@harran.edu.tr
}

Key words: Deficit irrigation, Water saving, Sweet corn, Yield characteristics

\begin{abstract}
This study was made to determine the influence of deficit irrigation on drip irrigated sweet corn in 1998 and 1999 in Sanliurfa, Turkey. Water was applied to sweet corn as 100, 90, 80 and 70\% of evaporation from a Class A Pan $\left(\mathrm{E}_{\mathrm{pan}}\right)$. Applied irrigation water was $610-876 \mathrm{~mm}$ and 612-889 $\mathrm{mm}$ in 1998 and 1999, respectively. Plant height, ear length, number of kernels per ear and single fresh ear weight values were the highest at $100 \% \mathrm{E}_{\mathrm{pan}}$ whereas the lowest values were found at $70 \% \mathrm{E}_{\mathrm{pan}}$ in both the years. Water savings were $11.30,20.89$ and $30.36 \%$ in 1998 and $10.91,21.14,31.15 \%$ in 1999 for 90,80 and $70 \%$ of $\mathrm{E}_{\text {pan }}$, respectively. The highest fresh ear yields (14.76 and $14.17 \mathrm{tha}^{-1}$ ) were obtained at $100 \% \mathrm{E}_{\mathrm{pan}}$, whereas minimum fresh ear yields (9.15 and $8.84 \mathrm{t} \mathrm{ha}^{-1}$ ) were found at $70 \%$ of $\mathrm{E}_{\mathrm{pan}}$ in 1998 and 1999, respectively. Despite the reduction of fresh ear yield, the number of marketable ears at $10 \%$ water deficiency $\left(90 \% \mathrm{E}_{\mathrm{pan}}\right)$ was still high and acceptable for sweet corn production in the Harran Plain of Turkey.
\end{abstract}

\section{Introduction}

The primary purpose of one of the world's largest irrigation project in Turkey is to provide a more stable supply of food for the world population, which is increasing rapidly. A national development project, South-eastern Anatolian Project, widely known by the acronym (GAP) in Turkish, has an economical importance due to its value addition effects on the soil and water resources in the region. With the completion of GAP, irrigated land area will reach up to 1.7 million ha and plant diversity will increase in the region. Sweet corn will be cultivated for the first time in the GAP area.

Currently, traditional irrigation methods, which are known to increase amount of surface runoff, are used in this region. Drip irrigation provides the efficient use of limited water due to reduce surface water evaporation (Viswanatha et al. 2002). Deficit irrigation is a system by which maximum yield may be obtained with less irrigation water.

Effects of deficit irrigation for corn were reported by some researchers. Dagdelen et al. (2006) reported that water deficiency significantly affected corn yield and the highest corn yield was obtained from the full irrigation treatments. Viswanatha et al. (2002) stated that yield decreased with reduced irrigation water. Pandey et al. (2000a) reported that yield reduction (22.6 - 26.4\%) were found with deficit irrigation and this was associated with decrease in kernel number and weight. Stone et al. (2001b) reported that water deficit reduces crop growth, canopy development, and morphological characteristics of corn plant. Karam et al. (2003) stated that water deficiency significantly reduced dry matter accumulation. Grain yield reduced to $37 \%$ due to a decline of $18 \%$ in kernel weight and of $10 \%$ in kernel number under water stress conditions. Stone et al. (2001b) reported that water deficit reduced morphological characteristics of corn plant. Pandey et al. (2000a) reported that water stress reduced kernel number and weight, and yield.

The aim of this study was to obtain irrigation water saving with deficit irrigation, to reach satisfactory yield level using deficit irrigation, to determine the influence of deficit irrigation on yield and some morphological characteristics of sweet corn using drip irrigation system. 


\section{Materials and Methods}

This study was conducted during 1998 and 1999 at the Sanliurfa, Turkey. The experimental field is located at Harran Plain (altitude: $465 \mathrm{~m} ; 37^{\circ} 08^{\prime} \mathrm{N}$ and $38^{\circ} 46^{\prime} \mathrm{E}$ ) in the Southeast Turkey. The texture of the soil of experimental field was clay. Field capacity of the soil was $33.8 \%$ (dry basis), permanent wilting point was $22.6 \%$ and bulk density of the soil was $1.41 \mathrm{~g} / \mathrm{cm}^{3}$. The air temperatures were all above $40^{\circ} \mathrm{C}$ while the relative humidity was below $50 \%$ in June, July and August for both the treatment years.

Hybrid sweet corn variety (Zea mays saccharata Sturt), Martha, was used as the crop material. The experiment was laid out in a randomized block design with three replications. Each plot consisted of four rows of $5 \mathrm{~m}$ in length. The distance between rows and plants were $70 \mathrm{~cm}$ and $20 \mathrm{~cm}\left(7.1\right.$ plants $\left.\mathrm{m}^{2}\right)$. The seeds were sown at a 50-60 mm depth. At sowing, $80 \mathrm{~kg} \mathrm{~N} / \mathrm{ha}$ and $\mathrm{P} / \mathrm{ha}\left(\mathrm{P}_{2} \mathrm{O}_{5}\right)$ as $20-20-0$ fertilizer was applied to each plot and this was followed by $160 \mathrm{~kg} / \mathrm{ha} \mathrm{N}$ as urea when the plant reached 30-40 cm height. Ears from two rows in the centre of each plot (50 plants) were manually harvested. Plant height values were measured on randomly selected 20

plants in the centre of every plot before harvest. Randomly selected 20 ears without husk were used for determining of ear lengths, ear diameters, kernel numbers per ear and single fresh ear yield values.

First irrigation was applied to all treatments using a sprinkler irrigation system to bring the soil water content in $0-90 \mathrm{~cm}$ soil depth up to field capacity in both years. Irrigation treatments were started using surface drip irrigation system when the water content of soil decreased to $50 \%$ of available soil water.

The amount of irrigation water was calculated using the equation given below,

$$
\mathrm{I}=\mathrm{A} \cdot \mathrm{E}_{\mathrm{pan}} \cdot \mathrm{K}_{\mathrm{cp}} \cdot \mathrm{CAI}
$$

where, $I$ is the amount of irrigation water $(\mathrm{mm})$, A is plot area $\left(\mathrm{m}^{2}\right), \mathrm{E}_{\mathrm{pan}}$ is cumulative water depth in the Class A pan $(\mathrm{mm}), \mathrm{K}_{\mathrm{cp}}$ is the crop pan coefficient [determined as $100\left(\mathrm{~K}_{\mathrm{cp} 1}\right), 90\left(\mathrm{~K}_{\mathrm{cp} 2}\right)$, $80\left(\mathrm{~K}_{\mathrm{cp} 3}\right)$ or $70 \%\left(\mathrm{~K}_{\mathrm{cp} 4}\right)$ of the total evaporation from the Class A pan], and CAI is the canopy area index, which was assumed to be 1 .

The total evaporation from Class A Pan was measured every day with a manual limnimeter with $0.1 \mathrm{~mm}$ accuracy. These measurements were checked with the readings from the water flow meters mounted in every plot.

Applied irrigation water was 876, 777, 693 and $610 \mathrm{~mm}$ in 1998 and 889, 792, 701 and 612 $\mathrm{mm}$ in 1999 for $100,90,80$ and $70 \% \mathrm{E}_{\mathrm{pan}}$, respectively. The data obtained from the experiments were analysed with ANOVA and LSD tests.

\section{Results and Discussion}

The highest fresh ear yield values were determined at $100 \% \mathrm{E}_{\text {pan }}(14.76$ and $14.17 \mathrm{t} / \mathrm{ha}$ ) while the lowest values were obtained from $70 \% \mathrm{E}_{\mathrm{pan}}(9.15$ and $8.84 \mathrm{t} / \mathrm{ha})$ in 1998 and 1999, respectively. Water deficiency decreased fresh ear yield (Table 1, Fig. 1). Some researchers stated that yield decreased with reduced irrigation (Eck 1984, Pandey et al. 2000a, Viswanatha et al. 2002).

The rates of water savings were 11.30, 20.89 and $30.36 \%$ in 1998 and 10.91, 21.14 and $31.15 \%$ in 1999 for 90,80 and $70 \% \mathrm{E}_{\text {pan }}$, respectively. During the both research years, a decrease was observed in fresh ear yield values as 6.8, 17.2 and 37.9\%, when the water applied 90, 80 and $70 \% \mathrm{E}_{\text {pan }}$, respectively. Although the yield decreased $(6.8 \%)$, marketable ear numbers were relatively stable at the $90 \% \mathrm{E}_{\mathrm{pan}}$. There was no statistically significant difference between fullirrigated treatment and $90 \% \mathrm{E}_{\mathrm{pan}}$ for marketable ear numbers (Fig. 2). Marketable ear numbers have economic value as such as total fresh ear yield and ear length in the upper $170 \mathrm{~mm}$ for sweet 
corn is preferred (Oktem and Oktem 1999). The aim of irrigation is to enhance economic returns with optimise the yield by minimising the damage caused by water deficiency during the crop development stages (Stone et al. 2001a). Deficiency at irrigation water as a 10\% (90\% $\mathrm{E}_{\text {pan }}$ ) can be acceptable for sweet corn production in the Harran Plain of Turkey.

Table 1. Effect of deficit irrigation on fresh ear yield, number of kernel per ear and tassel flowering.

\begin{tabular}{|c|c|c|c|c|c|c|c|c|c|}
\hline \multicolumn{4}{|c|}{$\begin{array}{c}\text { Fresh ear yield }^{1} \\
\text { (t/ha) }\end{array}$} & \multicolumn{3}{|c|}{$\begin{array}{l}\text { Number of kernel per ear } \\
\text { (kernel/ear) }\end{array}$} & \multicolumn{3}{|c|}{$\begin{array}{l}\text { Tassel flowering } \\
\text { (day) }\end{array}$} \\
\hline $\begin{array}{l}\text { Irrigation } \\
\text { treatments }\end{array}$ & $1998 * *$ & $1999 * *$ & Mean** & $1998 * *$ & $1999 * *$ & Mean* & $1998 * *$ & $1999 * *$ & Mean** \\
\hline $100 \% \mathrm{E}_{\mathrm{pan}}$ & $14.76 \mathrm{a}^{\dagger}$ & $14.17 \mathrm{a}$ & $14.47 \mathrm{a}$ & $551.3 \mathrm{a}$ & $576.7 \mathrm{a}$ & $564.0 \mathrm{a}$ & $48.33 \mathrm{~d}^{\dagger}$ & $48.67 \mathrm{c}$ & $48.50 \mathrm{~d}$ \\
\hline $90 \% \mathrm{E}_{\mathrm{pan}}$ & $13.85 \mathrm{a}$ & $13.11 \mathrm{a}$ & $13.48 \mathrm{a}$ & $521.7 \mathrm{a}$ & $524.6 \mathrm{~b}$ & $523.1 \mathrm{a}$ & $50.00 \mathrm{c}$ & $51.67 \mathrm{bc}$ & $50.83 \mathrm{c}$ \\
\hline $80 \% \mathrm{E}_{\mathrm{pan}}$ & $12.34 \mathrm{~b}$ & $11.63 \mathrm{~b}$ & $11.98 \mathrm{~b}$ & $445.3 \mathrm{~b}$ & $457.3 \mathrm{c}$ & $451.3 \mathrm{~b}$ & $52.67 \mathrm{~b}$ & $53.67 \mathrm{~b}$ & $53.17 \mathrm{~b}$ \\
\hline $70 \% \mathrm{E}_{\mathrm{pan}}$ & $9.15 \mathrm{c}$ & $8.84 \mathrm{c}$ & $8.99 \mathrm{c}$ & $404.0 \mathrm{c}$ & $339.7 \mathrm{~d}$ & $371.9 \mathrm{c}$ & $55.33 \mathrm{a}$ & $58.33 \mathrm{a}$ & $56.83 \mathrm{a}$ \\
\hline Average & 12.53 & 11.94 & 12.23 & 480.58 & 474.58 & 477.58 & 51.58 & 53.08 & 52.33 \\
\hline LSD & 1.08 & 1.27 & 1.10 & 36.61 & 49.13 & 51.87 & 1.597 & 3.60 & 1.48 \\
\hline
\end{tabular}

${ }^{1}=$ Fresh ear yield is husked. $* * *=$ Significant at the $\mathrm{P}<0.05$ and $\mathrm{P}<0.01$ probability levels, respectively.

In a vertical column numericals having same alphabet do not differ significantly at $5 \%$ and $1 \%$ levels according to LSD

Number of kernels per ear decreased with increasing deficiency in irrigation water (Table 1). Similar findings were reported by Eck (1984 and 1985), Braunworth et al. (1987), Grant et al. (1989) and Pandey et al. (2000a). Number of kernels is closely associated with yield of maize and the number of kernels per ear is a yield component that varies markedly with stress (Fischer and Palmer 1984). Harder et al. (1982) mentioned that water stress caused failure of kernel development, its number, size and weight.

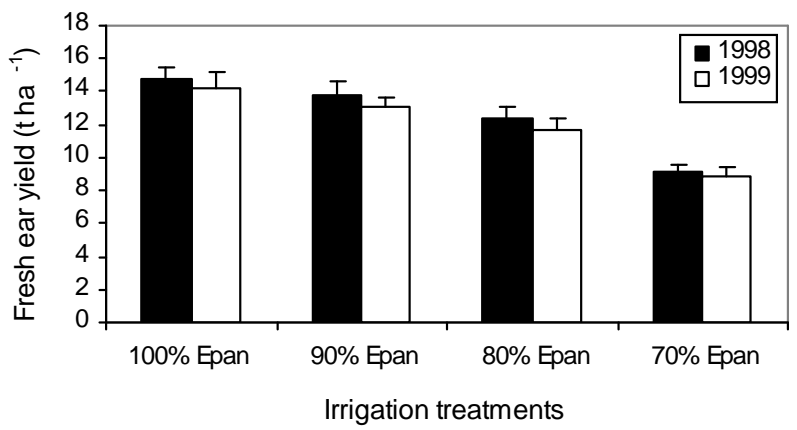

Fig. 1. Fresh ear yield values at different irrigation treatments in 1998 and 1999.

Vertical bars indicate standard errors of the mean.

Pandey et al. (2000a) stated that kernels per ear were reduced from $20 \%$ to nearly $50 \%$ due to water stress. There is a general agreement that final kernel number is established about two to three weeks after pollination (Kirtok 1998). Any stress imposed during this period greatly affects kernel set. Andrade et al. (1999) demonstrated that a limited partitioning of dry matter to reproductive tissues during the critical period (bracketing silking) results in low numbers of kernel set. Furthermore, ovules remain undeveloped resulting in many kernels being small and light in weight. NeSmith and Ritchie (1992) found that yield reduction in maize was attributable to a reduction in the number of well developed kernels. Pandey et al. (2000a) stated that yield reduction was associated primarily with decrease in kernel number and secondarily with kernel weight when deficit irrigation was imposed during vegetative and reproductive phases of growth. 
Tassel flowering was longer with increasing water stress (Table 1). Tassel flowering ranged between 55.33 and 51.58 days in 1998 and between 48.67 and 58.33 days in 1999. Oteigui et al. (1995) reported that corn grain yield is particularly sensitive to water deficits that coincide with the tasselling-silking period and emergence of tassels was delayed more than two weeks. Edmeades et al. (1990) reported that tassel flowering period was longer due to water stress conditions.

Table 2. Effect of deficit irrigation on plant height, ear length and single fresh ear weight.

\begin{tabular}{|c|c|c|c|c|c|c|c|c|c|}
\hline \multicolumn{4}{|c|}{ Plant height $(\mathrm{cm})$} & \multicolumn{3}{|c|}{ Ear length $(\mathrm{cm})$} & \multicolumn{3}{|c|}{ Single fresh ear weight ${ }^{1}(\mathrm{~g})$} \\
\hline $\begin{array}{l}\text { Irrigation } \\
\text { treatments }\end{array}$ & $1998 * *$ & $1999^{*}$ & Mean* & $1998 * *$ & $1999 *$ & Mean** & $1998 * *$ & $1999 * *$ & Mean* \\
\hline $100 \% \mathrm{E}_{\mathrm{pan}}$ & $177.3 \mathrm{a}$ & $169.0 \mathrm{a}$ & $173.1 \mathrm{a}$ & $19.97 \mathrm{a}^{\dagger}$ & $19.03 \mathrm{a}$ & $19.50 \mathrm{a}$ & $255.3 \mathrm{a}^{\dagger}$ & $243.7 \mathrm{a}$ & $249.5 \mathrm{a}$ \\
\hline $90 \% \mathrm{E}_{\mathrm{pan}}$ & $171.7 \mathrm{ab}$ & $158.0 \mathrm{ab}$ & $164.9 \mathrm{~b}$ & $18.33 \mathrm{~b}$ & $18.13 \mathrm{a}$ & $18.23 \mathrm{~b}$ & $217.7 \mathrm{~b}$ & $213.0 \mathrm{~b}$ & $215.4 \mathrm{a}$ \\
\hline $80 \% \mathrm{E}_{\mathrm{pan}}$ & $169.6 \mathrm{~b}$ & $150.0 \mathrm{~b}$ & $159.8 \mathrm{~b}$ & $17.40 \mathrm{c}$ & $16.77 \mathrm{ab}$ & $17.08 \mathrm{c}$ & $211.7 b$ & $193.0 \mathrm{c}$ & $202.3 \mathrm{ab}$ \\
\hline $70 \% \mathrm{E}_{\mathrm{pan}}$ & $156.7 \mathrm{c}$ & $142.3 \mathrm{~b}$ & $149.5 \mathrm{c}$ & $16.27 \mathrm{~d}$ & $15.40 \mathrm{~b}$ & $15.84 \mathrm{~d}$ & $203.0 \mathrm{~b}$ & $119.3 \mathrm{~d}$ & $161.2 \mathrm{~b}$ \\
\hline Average & 168.8 & 154.8 & 161.8 & 17.99 & 17.33 & 17.66 & 221.93 & 192.25 & 207.1 \\
\hline LSD & 7.15 & 17.83 & 5.99 & 0.737 & 2.675 & 0.435 & 20.22 & 13.73 & 47.34 \\
\hline
\end{tabular}

*** : Significant at the $\mathrm{P}<0.05$ and $\mathrm{P}<0.01$ probability levels, respectively. ${ }^{1}$ : Husked single fresh ear weight In a vertical column numericals having same alphabet do not differ significantly at $5 \%$ and $1 \%$ levels according to LSD

Taller plants were found at $100 \% \mathrm{E}_{\mathrm{pan}}$ whereas short plants were seen at $70 \% \mathrm{E}_{\mathrm{pan}}$ (Table 2). Plant height is a good indicator for determining the water stress. Sammis et al. (1988) reported that plant height can change at different level water deficiency. Some authors emphasized that deficit irrigation shortened plant height (Otegui et al. 1995, Stone et al. 2001a and Pandey et al. 2000b).

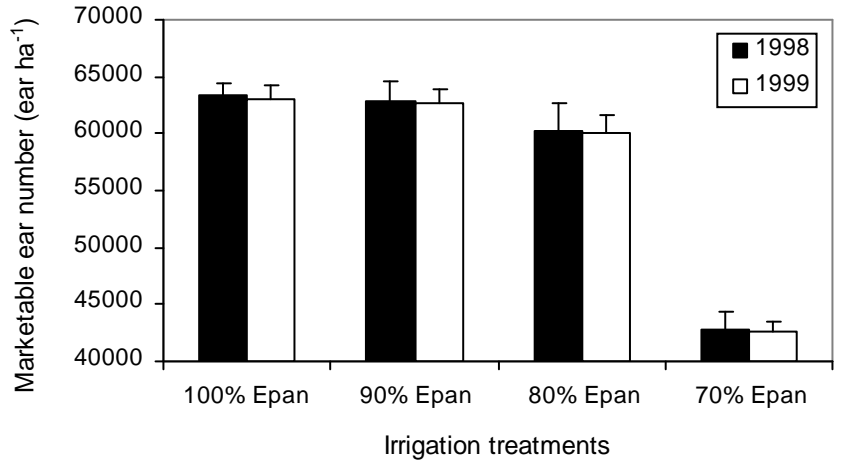

Fig. 2. Marketable ear number values at different irrigation treatments in 1998 and 1999.

Vertical bars indicate standard errors of the mean.

The longest ears were measured at $100 \% \mathrm{E}_{\mathrm{pan}}$, whereas the shortest ears were observed at $70 \%$ $\mathrm{E}_{\mathrm{pan}}$ in both the years (Table 2). Ear length decreased with increasing water deficiency. Single fresh ear weight values decreased with increasing deficit irrigation. Eck (1985) stated that water deficiency at grain filling period reduces kernel weight per ear values. The potential yield of maize is determined by kernel weight (Jacobs and Pearson 1991), it is a certainty that shortage of water stress reduces grain yield by reducing kernel weight per ear (Kirtok 1998). Karam et al. (2003) reported that grain yield reduced to $37 \%$ under water stress conditions. This reduction was due to a decline of $18 \%$ kernel weight and $10 \%$ in kernel number as a response to water deficit. 
As a result, despite the reduction of fresh ear yield, the number of marketable ears at $10 \%$ water deficiency $\left(90 \% \mathrm{E}_{\mathrm{pan}}\right)$ was still high and acceptable for sweet corn production in the Harran Plain of Turkey.

\section{References}

Andrade, F.H., C. Vega, S. Uhart, A. Cirilo, M. Cantarero and M. Valentinuz. 1999. Kernel number determination in maize. Crop Sci. 39: 453-459.

Braunworth Jr, W.S. and H.J. Mack. 1987. Effect of deficit irrigation on yield and quality of sweet corn. J. Amer. Soc. Hort. Sci. 112(1): 29-32.

Dagdelen, N., E. Y1lmaz, F. Sezgin and T. Gurbuz. 2006. Water-yield relation and water use efficiency of cotton and second crop corn in western Turkey. Agric. Water Management 82(1-2): 63-85.

Eck, H.V. 1984. Irrigated corn yield response to nitrogen and water. Agron. J. 76: 421-428.

Eck, H.V. 1985. Effect of water deficit on yield, yield components and water use efficiency of irrigated corn. Agron. J. 78: 1035-1040.

Edmeades, G.O., J. Bolanos and H.R. Lafitte. 1990. Selecting for drought tolerance in maize adapted to the lowland tropics. The $4^{\text {th }}$ Asian Regional Maize Workshop, Sept. 23-27, 1990, Islamabad, Pakistan.

Fischer, K.S. and F.E. Palmer. 1984. Tropical Maize. In: The Physiology of Tropical Field Crops. Goldsworthy, P.R., N.M. Fischer, (Eds.), Wiley, New York. pp. 213-248.

Grant, R.F., B.S. Jackson, J.R. Kiniry and G.F. Arkin. 1989. Water deficit timing effects on yield components in maize. Agron. J. 81: 61-65.

Harder, D., R.E. Carlson and R.H. Shaw. 1982. Yield and yield components and nutrient content of corn grain as influenced by post-silking moisture stress. Agron. J. 174: 275-278.

Jacobs, B.C. and C.J. Pearson. 1991. Potential yield of maize determined by rate of growth and development of ears. Field Crops Res. 27: 281-298.

Karam, F., J. Breidy, C. Stephan and J. Rouphael. 2003. Evapotranspiration, yield and water use efficiency of drip irrigated corn in the Bekaa Valley of Lebanon. Agric. Water Management 63(2): 125-137.

Kirtok, Y. 1998. Corn production and use. Kocaoluk Press, Istanbul, Turkey pp. 445.

NeSmith, D.S. and J.R. Ritchie. 1992. Short- and long-term response of corn to a preanthesis soil water deficit. Agron. J. 84: 107-113.

Oktem, A. and A.G. Oktem. 1999. Determination of fresh ear yield, grain yield and important agronomical characteristics of some sweet corn varieties. I. GAP Agriculture Congress, 26-28 May, Sanliurfa, Turkey pp. 893-900

Otegui, M. E., F.H. Andrade and E.E. Suero. 1995. Growth, water use, and kernel abortion of maize subjected to drought at silking. Field Crops Res. 40(2): 87-94.

Pandey, R.K., J.W. Maranville and A. Admou. 2000a. Deficit irrigation and nitrogen effects on maize in a Sahelian environment I. Grain yield and yield components. Agric. Water Management 46: 1-13.

Pandey, R. K., J.W. Maranville and M.M. Chetima. 2000b. Deficit irrigation and nitrogen effects on maize in a Sahelian environment II. Shoot growth, nitrogen uptake and water extraction. Agric. Water Management 46(1): 15-27.

Sammis, T.W., D. Smeal and S. Williams. 1988. Predicting corn yield under limited irrigation using plant height. Transactions of the ASAE (Amer. Soc. Agric. Engineers) 3(13): 830-838.

Stone P.J., D.R. Wilson, J.B. Reid and R.N. Gillespie. 2001a. Water deficit effects on sweet corn. I. Water use, radiation use efficiency, growth, and yield. Aust.J.Agric. Res. 52: 103-113.

Stone P.J., D.R. Wilson, P.D. Jamieson and R.N. Gillespie. 2001b. Water deficit effects on sweet corn. II. Canopy development. Aust.J.Agric. Res. 52: 115-126.

Viswanatha, G.B., B.K. Ramachandrappa and H.V. Nanjappa. 2002. Soil-plant water status and yield of sweet corn as influenced by drip irrigation and planting methods. Agric. Water Management 55: 85-91.

(Manuscript received on 30 December, 2007; revised on 3 August, 2008) 